\title{
Education for Peace and Justice in Nigeria: A Critical Analysis 1999 - 2015
}

\author{
Mashud Layiwola Adelabu Salawu ${ }^{1, *} \&$ Simeon Abiodun Aina ${ }^{2}$ \\ ${ }^{1}$ Department of Political Science and International Relations, Southwestern University, P.M. B. 2088, Okun Owa, \\ Ijebu Ode, Nigeria \\ ${ }^{2}$ Faculty of Social and Management Sciences, Southwestern University, P. M.B 2088, Okun Owa, Ijebu Ode, Nigeria \\ *Correspondence: Department of Political Science and International Relations, Southwestern University, P.M. B. \\ 2088, Okun Owa, Ijebu Ode, Nigeria. E-mail: adesal2@yahoo.com
}

Received: November 28, 2016

Accepted: December 5, 2016 Online Published: January 25, 2017

doi:10.5430/wjss.v4n1p40

URL: http://dx.doi.org/10.5430/wjss.v4n1p40

\begin{abstract}
The arrays of violent conflicts in Nigeria, and government's reaction to them, through the application of adversarial hard powe, call for a review of governments, conflict handling styles. Since the advent of civilian administration in 1999, education for peace and justice has not got the required impetus, and it should be at the bedrock of any developing country's master plan. The theory of pacifism, coined by the French peace campaigner, Emile Armand (2016), that peaceful, rather than violent or belligerent relations should govern human intercourse, was applied. This paper observed the prevalence of conflict in Nigeria, ranging from ethic and relations violence, Niger Delta crises, Boko Haram insurgency, communal conflicts, political violence, kidnapping, as well as the bombardment of courts with political litigations among others. Lack of awareness of other non-adversarial methods of resolving conflicts has led to its unabatedness, which has cost the country so much loss in human and material resources.

This paper recommends that education peace and justice should be designed in a number of ways such as in workshop and awareness campaigns. The formal channels must be well staffed with people grounded in peace and conflict studies, to be complemented with train-the trainers approach, in order to ensure suitable knowledge transfer.

Government must exhibit good governance. As the level of illiteracy is high in the country, informal education for peace and justice must be given greater emphasise. The use of internet and other means of information technology will promote the dissemination of education for peace and justice in Nigeria.
\end{abstract}

Keywords: conflict, education, justice, Nigeria, peace

\section{Introduction}

Nigeria is in dire need of education for peace and justice. The desire for this is due to the avoidable arrays of conflicts and violence she has been experiencing since she became an independent nation and particularly, since the return of democratic governance in 1999. If the state actors have spared time, at the embryonic stage of the country's independence, to inculcate in the entire citizenry what education for peace and justice portends, conflicts and violence, emanating from power seeking, would have been avoided or minimized. Nigeria has not conducted a violence - free election since 1964, while fiscal federalism bequeathed on Nigeria by the Colonial Masters, and which worked throughout the First Republic, was terminated abruptly by the military. Responding to why and how by the powers that be on revenue allocation remains a daily issue since then. The Niger Delta region of Nigeria from where the contention oil emanates and the source of about ninety percent of the county's revenue, knows no tangible development, for which the youth there are restive. Rather than engage in dialogue with the power that be, they respond by vandalizing oil-pipe lines, which result in environmental degradation. This is surely counter - productive because beside the overall economic loss the whole country suffers, the hazardous effect of oil-spillage is more felt by the people living in the area of damage. The attendant diseases are scaring enough.

Religious conflicts, arising from religious propaganda and counter - religious propaganda have been manifesting in Nigeria, especially when propaganda is not kept within reasonable limits. Religions particularism is also prevalent, 
hence, religions organisations and those masquerading under religion, like the Boko Haram, have been perpetrating terror, to the disbelieve of the global community. If Nigerians from all the geo-political zone of the country have been sufficiently equipped about education for peace and justice, the perennial desire for power-at-any-cost would have been drastically reduced and over-emphasis on religion would have been checkmated .

Political conflicts in Nigeria derive from several sources. Power is a greater source of political conflicts and is always never enough for anyone who has it. Nigeria politicians do not accept defeat in an election. Hence, when every a candidate is defeated in an election, he or she rejects the result and resorts to confrontation. Ethnic groups in Nigeria give their national loyalty to their respective ethic interests, leaving nothing for nationalism and patriotism. Court judgement, regarding election petition or constitutional dispute may lead to conflict, especially when a court's decision favours a candidate who has been defeated in an election. The panacea of these self-generating social conflicts is deep impartation of education peace and justice. Through it, any action that may be adversarial to the growth and well-being of the society at large will be avoided, while any attempt to circumvent the laid - down rules in the society, with a new to institutionalizing any injustice against fellow country men and women will not be contemplated.

\subsection{Conceptual Clarification}

Two main concepts, peace education on one hand and education for peace and justice on the other hand, are considered germane for further clarification, in order to avoid any misrepresentation or ambiguity in their application. Peace education is about those processes for dealing with conflicts generally. It could be community, nationally or internationally based. Otite $(1999 ; 1)$ submits that "Conflicts arise from the pursuit of divergent interests, goals and aspirations by individuals and, or groups in defined social and physical environments. Changes in the social environments, such as contestable access to new political positions, or perceptions of new resources, arising from developments in the physical environment, are fertile grounds for conflicts involving individuals and groups, who are interested in using these new resources to achieve their goals”. The scholar therefore, admonishes people generally to realize that the nature of conflicts in heterogeneous societies, (such as Nigeria) is usually very competitive. However, in order to avoid self-destruction of such societies, people, more or less compellingly sustain their societies through the resolution, transformation and management of any emerging conflict.

It follows, therefore, that in order to secure a peaceful environment in which all elements of physical, psychological and structural violence are non-existent or are minimized, a process of profound, transforming situations for societies characterized by violence and fear, is inevitable. Through the process of peace education, an environment, in which reconciliation and social justice predominate, will emerge.

On the other hand, education for peace and justice, which this paper focuses, is the knowledge required for removing hindrances from the path of focus which laid down policies might have programmed. Ignorance is a weight disease which only education can remove. According to Sabine and Thorson (1973:68-69), education is the positive means by which the ruler can shape human nature in the right direction to produce a harmonious state... If the citizens are well educated, they will readily see through the difficulties that beset them and meet emergencies as they arise... If virtue is knowledge it can be taught and the educational system to teach it is the one indispensable part of a good state. The scholars further aver that with a good system of education, almost any improvement is possible; if education is neglected, its matters little what else a state does.

Complementing Sabine and Thorson (1973) is Appadorai (1974;106) who equivocally assert that popular education is necessary for the preservation of those conditions of freedom, political and social, which are essential to an unhindered individual development. It is necessary to keep the citizens adequately prepared for the task of citizenship. Further the great social problem of our day, the reduction of inequalities, is largely is largely a question of the provision of adequate opportunity, which again, is largely dependent on education. The scholars are reminding all and sundry, particularly state actors, that education must be seen as a great social investment for which funds must be sourced, if a society is to be programmed along the path of peace, inculcating peace as harmony, peace as justice, peace as order and peace as conflict management.

Various governments adopt series of methods to ensure a child secured the necessary minimum level of education. It may leave the education of the child to the care of the family. Yet it may direct that every child should receive a certain minimum level of education as a legal right and compel the family to provide it out of the family funds. Alternatively, it could order that every child must have schooling up to a certain age, and make education free by providing the necessary funds from its revenue. Empirically, modern states adopt this third option because the first and second experiments have not achieved the result anticipated. The euphemism that "if one want peace, he/she should programme for peace" has become an inevitable guide. For the purpose of securing obedience, progress, 
peace and justice, as well as non-violence, a deep knowledge of a citizen's rights and privileges is required. It is for a government to introduce policies geared towards good governance. If people are education about what the government has in stock for the populace, which leads to the introduction of any particular policy and the people in turn are allowed to have their say, it will result in a win-win situation for the government. That is the bedrock of democracy and that is the anchor of education for peace and justice.

\subsection{Theoretical Framework}

The need for the inculcation of education for peace and justice in Nigeria, in addressing the myriads of threaten combustibles and adversarial conflicts, could be better imagined, if we examine the imports of the theory of pacifism as envisioned by the French peace campaigner Emile Arnaud (http:iep.utm.edu/pacifism, citied on 29/10/2016) and adopted by other peace activists at the tenth universal peace congress in Glasgow in 1901 (Robbins, 1976:10). Ahinsa, meaning to do no having, is a related concept, which is core philosophy in Buddhism Jainism, as well as in Hinduism.

Pacifism covers a spectrum of views, incorporating the assumption that international, as well as internal disputes, could and should be peacefully resolved. It calls for the abolition of the institutions of the military and war, opposition to any organisation of society through state force, and a total rejection of the application of physical, structural or psychological violence to obtain political economic or social goals. Furthermore, pacifism is a call the obliteration of force and an opposition to violence under and any circumstance.

Brock and Socknat (1999:IX) posit that pacifism is analogous to an unconditional rejection of all forms of warfare while Teichman (1986) is of the new that the main form of pacifism is anti-warism rejecting any form of warfare. In summarizing, the views of Teichman (1986), Orend (2000:145-146) submit that a pacifist rejects was and believe there are no moral ground which can justify resorting to war. He concludes that war, for a pacifist, is always wrong. In short, the philosophy of pacifism is based on the idea that the ends do not justify the means.

Pacifism is the theory that emphasizes a peaceful, rather than a violent or belligerent relationship as a pre-condition to govern human intercourse and that arbitration surrender or migration and should be applied to resolve disputes

The philosophical study of pacification requires examining a variety of aspects of the broad proposal, as well as an investigation of its consequences. Pacifism relates to war as well as to domestic injustice injustices and repressive polices. It can be studied in terms of its coherence as a deontological or intrinsic value, as well as well as in terms of the beneficial effect it seeks Examination of the broad theory of pacifism will draw an overlapping attention to a broad range of possible ethical meanings and issues that both pacifists and critics must review. However, the relevance of this theory is about educations Nigerians on the need to have an advanced knowledge of government programmes and to avoid needless distractions due to ill-perception of government activities. Therefore, within the framework of this paper, while pacifists believes that human life is to valuable and that a human should never be killed, as well as the belief that war should never be conducted even, in self-defence. According to the British Broadcasting Corporation (2016), the principle is described as different to abide by consistently, due to violence not being available as a tool to aid person who is being harmed as killed. It is further claimed that such a pacifist could logically argue that violence leads to move undesirable result, than non-violence (BBC British Broadcasting Corporation, http:/www.iep.utm.edu/pacifism, retrieved29/10/2016). While the Deontologists say it is incumbent on the pacifist never to agrees, use force, or support or engage in war against another and seeing peace to be categorically upheld, other moralist argue for pacifism on the basis of its beneficial consequences, rather than on any intrinc notion of the goods anticipated.

The Nigeria government must see the inculcation of education for peace and justice as no-negotiable because its dearth is at the risk of various aggressive reaction by restive youths in all the geo-political zones of the country. These disturbances has caused Nigeria a colossal loss in both human and capital outlays, while the combatant too, should embrace dialogue as a penancea to any misperception of the state's policy.

\section{Why Emphasis Is To Be Placed On Education for Peace and Justice}

Scholars are of the view that since wars start in the minds of human beings, it becomes inevitable that it is in the minds of human beings as well that the defences of peace must be constructed. People are regularly being inundated with assumptions that the violence we hear of in many communities as well as those injustices being inflicted on people is a fact of life. In fact, several literature books dwell on battles and victories, glorifying victorious nations and casting rebukes on the countries defeated. The mass media are not spared from sensational reports about victors and vanquished, without educating the masses on how to cope with peaceful co-existence. 
In order to redress the anomaly, and to let people realize that they could share their pains and success with equanimity, education for peace and justice is emphasized. Education for peace and justice is forward looking, as it keeps asking for what could be the result if keeping animosity among the federating units continues to be the order of the day. It preaches attitudes of self-respect, tolerance, empathy, justice and fairness. It frowns at passive attitudes to issues concerning the welfare of the community but encourages active and open-minded contributions to societal upliftment.

Education for peace could be viewed as a long-term based programme focusing on trends of a society and through educational institutions or may be focused at those activities through informal settings.

\subsection{Using Formal Platforms to Enhance Education for Peace}

The formal terrains for imparting peace education are Schools, Colleges and Tertiary Institutions. Owing to those pervading conflicts in Nigerian society, the Federal Ministry of Education, through the National Universities Commission, directed that peace education must be included in the Curriculum of Schools, Colleges and Universities, with a view to imparting in the citizenry living in harmony and avoiding injustice to others. The subject areas under which peace education comes up are Religions Education, History, Geography, Science, Literature, and many others. Under religious education, areas of concentration include the peace messages from each religion. In the contemporary international system, there are many religions and each has a way of sending peace messages. For example, in Christianity, the Pope of Rome, whether at Christmas, Good Friday, Easter or any occasion warranting the concentration of fellow worshippers, preaches love, peace, justice, avoidance of conflict and mitigation of any sign of acrimony anywhere in the international community. The Pope once visited Nigeria when the voice of the oppressed got to his hearing. So worried was the Vatican that the Pope even appealed for cessation of oppression and self-inflicted injuries in Nigeria and approached the then Head of the Federal Military Government, General Sanni Abacha to temper justice with mercy in the ongoing trial of Nigerians. All appeals for peace by the Pope to the then Nigeria's Head of State were derided. The Ogoni Nine were hanged while many notable Nigerians facing Military tribunals had the wrath of Nigeria's maximum leader. The rest is history. Besides, Christian religious knowledge is a course of study in primary, secondary and Tertiary education systems in Nigeria for the purpose of inculcating peace education and imparting knowledge about avoidance of injustice to others. The Holy Bible, which is the acknowledged Literature for Christians globally, is loaded with messages and case-studies of peace and conflict resolution. These could be gleaned from Genesis and up to Revelation.

Speaking on religion and international relations, John Anderson (2008), cited by Salmon and Inber (2008:213), writes elaborately on religions contributions to politics, which he says has often involved conflict or violence, but of equal importance are the roles played by religious organizations and ideas in achieving peaceful political transformations and conflict resolution, or the so called third wave of democratization... "At the Second Vatican Council (1962-5), the Catholic Church adopted a series of ecclesiastical reforms that gave the Catholic Church's qualified approval to democracy, human rights and freedom of conscience. In turn, this led to a growth of Catholic activism in criticizing human rights abuses and speaking up for the victims of repression, promoting and defending civil society organizations and offering support services as mediators or negotiators in the process of political change”. Anderson (2008:213) equally educates the people that the critiques of authoritarian regimes focus their attention on social injustice, with Bishops and Priests lambasting those narrow-inclined economic policies that deprived the poor of land or income, as well as the rebuking of those landlords whose abuses were being backed by the retrogressive forces of the state.

While commending the religious organizations on their concerns for social justice, disdain for economic exploitation and willingness to rebuke perpetrators of violence in all its ramifications, he eulogizes the growing movement of the civil society in the creation of organizations to defend human rights in practical ways, such as providing legal aid to assist the needy poor, and in helping to carry out meticulous investigations of abuses globally. Both state and non-state actors, as complimentary stake holders in the contemporary international system, will not forget in a hurry the Catholic Church's campaign for change in social mannerisms, strengthened by the election of Pope John Paul II in 1978, who used his position to promote human rights around the world and to criticize those who adopted more radical political positions. These major references are eloquently inculcated through formal education for peace and justice.

Islam, as a religion, is for peace, justice, humility, humanitarianism and all that will promote societal happiness. Millions of Muslims pay pilgrimage to the Holy land of Mecca and Medina annually where prayers are offered for world peace on Mount Arafat. This is besides fervent prayers at the greatest Mosque of Kaaba and the Holy Prophets Mosque in Medina. Going on pilgrimage to the Holy land, at least, once a year, has been the prayer of millions of 
people globally and many adherents, male and female, have inculcated Islamic tenets and education, up to the level of being a great asset to the international community. They eschew injustice, violence, immorality and any vice that could smear Islam as a religion. It is through formal peace education that case studies of those who adhere to the teachings of the Qu'aran, as well as of the impostors are learnt and recorded for dissemination to both far and near.

According to, Andrea Teti (2008), cited in Salmon and Imber (2008:218) "the use of religion as a banner for political opposition is an age-old phenomenon that has its contemporary roots in European imperialism, especially the Ottoman Empire and the fierce debates about whether or not shared religion could provide the necessary solution to the empire's cross-border weakness....

Through formal education for peace and justice, it will be captured that one of the many poorly understood aspects of Islam is its jurisprudence. Sharia is explained as a body of legal scholarship on the basis of which individual legal codes can be drawn up. Furthermore, formal education for peace and justice will throw more light on Sharia, which is not a specific legal code or Islamic law but rather, a field of legal scholarship, based on the principles contained in the Qur'an and the Hadith. Other Islamic concept such as dhimma, shura and ijtihal, which preach peace, analogy and many other issues emphasize absolute peace and justice.

"Dimma is a formulation allowing non-Muslims (especially

ahla-kitab or People of the Book, Jews, Christians, Sabeans and

Zoroastrians) to live freely in Muslim States in their own

communities and governed by their own laws, as long as they

pay a small tax. This system of communities known as millet allowed

the peaceful co-existence of different faiths within the same territories". (Teti, 2008: 220)

Indeed, it is through peace education that people could realize the truth or falsehood in any invitation to religious fundamentalism by any group of people or any individual. Knowledge is power.

The relevance of history as a formal course of study in peace education is that it elicits significant examples on non-violence and peace building propensities when viewed along those quantifiable and unquantifiable damages which violence has inflicted on the society, as well as those innumerable social fabrics that have been blurred perpetually. Through historical erudition by notable members of the academia such as Ajayi and Smith (1964), Law, (1970), Akinjogbin (1965, 1966, 1992), Akintoye (1971) Johnson (1971), and many others, the authentic historical sequence of the Ife-Modakeke crisis, one of the oldest intra-ethnic conflicts in Nigeria, which is more than a century old, would not have been known, if not channeled through formal institutions. The conflict historian who compiled these conflict and peace building activities for posterities is Albert (1999: 142-183). This scholar keeps championing education for peace and justice through both formal and informal settings, in both developing and developed countries.

Without any doubt, the civil wars in Yorubaland of Nigeria which could have torn the tribe apart, including the conflicts between the kingdoms of the North and South of Nigeria were meticulously handled and the conflict resolution mechanisms therein are being adopted to tackle the issues arising from them in today's contemporary international system, as it affects the geo-political zones of Nigeria (Ikme, 1984). Hardly a day passes without recalling the greatest hot-spot of the global system, the Middle-East. Many libraries in Primary, Secondary, Colleges and Tertiary Institutions are fully stocked to enable students and the young-at hearts catch a glimpse of events in the Middle Eastern region of the global community. In short, the study of history, in a formal sphere, enables various episodes, from causes, courses and resolution mechanisms, to be studied in good details. Within the discipline of history as a course of study, we have economic history, social history, cultural history, environmental history, political history of a people or race and so on and so forth. In a nutshell, the study of history in a formal setting is an asset to disseminating contents of education for peace and justice.

The study of geography as a discipline in formal institutions of learning is multifarious. Besides tackling prejudice, it shows the deep inter-relatedness of peoples across the globe. The world is shrinking, says Nye Jnr. (2007). The Mayflower took three months to cross the Atlantic. In 1924, Charles Lindborgh's flight took 33 hours. Fifty years later, the Concorde did it in three hours. Ballistic missiles can do it in 30 minutes. At the beginning of the $21^{\text {st }}$ Century, a transatlantic flight-costs one third of what it did in 1950, and a call from New York to London costs only a small percentage of what it did at mid-century. Global internet, communications, are nearly instantaneous and transmission costs are negligible. An environmentalist in Asia or a human rights activist in Africa today has a power of communication, once enjoyed only by large organizations such as governments or transnational corporations (Nye, 
Jnr. 2007: 1 \& 2). These are to show the relevance of geography as a course of study in our educational institutions. Furthermore, it is emphasized that the study of geography is not only to see people as being completely inter-related, but also to understand that the global community is indeed shrinking and at the same time, fleeting, that is, it is moving speedily and silently away. These are peace building invocations because peace and justice begin where people do unto others as they would wish others to do unto them.

As a further prove of geography for inviting the attention of human beings all over the globe to their inter-connectedness, strategic studies point glaringly to the effect of both nuclear and conventional weapons. If borders have any artificial boundary, the atmosphere has none, empirically. Little wonder then why studies in formal institutions remind people of how an atomic bomb tested by France in 1960, in Sahara Desert, thousand of kilometers away from Nigeria, caused influenza fever there, killing many aged people, whose physique could not withstand the devasting atmospheric effect-of the launch. "Nuclear weapons have added a new dimension to war that one writer calls it 'double death", meaning that not only could individuals die, but under some circumstances, the whole human species could be threatened. This is a reminder of the Cuban Missile Crises of 1962 between the United States and the Sovet Union. Perhaps, as the September, 2001 terrorist attacks on New York and Washington illustrated, technology is putting into the hands of non-state actors destructive powers that once were reserved solely to governments. As the effects of distance shrink, (apology to geography), conditions in remote poor countries.... become highly relevant to America and Europe”. (Nye Jnr. 2007:2).

Our next area of attention, under which peace education could be inculcated in formal Institutions is Science as a course of study. Scientific studies are of two types. One is Pure Science and the other is Social Science. "We often associate Science with some of the noteworthy achievements of the modern era. Science played important roles in developing cures or vaccines for various diseases (for example, polio, small pox), in sending human beings into space, in developing new products like plastic, in making new weapons of mass destruction such as nuclear bombs, and in inventing or creating a whole host of things that surround us in everyday life in the twenty-first Century (Dahl, 2003:143).

Equally subscribed to by many scholars is the view that science is profoundly associated with academic disciplines like Chemistry, Biology and astronomy. On the same terrain, Social Science disciplines such as Economics, Sociology, Political Science, International Relations, Business Administration, Mass Communication and many others, are academic disciplines taught in various institutions globally. In short, "Science is a branch of study in which knowledge is organized around empirically confirmed general laws. The discovery of such laws is a principal object of scientific inquiry. Science is a systematic search for knowledge of the universe and its contents. It is generally agreed that for a statement or proposition to be scientific, it must be verifiable (Oyediran 2003:4). Essentially, science is being studied as a discipline for the purpose of inculcating peace education, because it keeps raising questions about human needs, as well as scientific responsibility. The study of science banishes ignorance and illiteracy. Facts are laid bare.

At this juncture, it is necessary to dwell on the part that literature is playing in the formal education for peace and justice. Unavailability of books to teach peace and conflict programmes in the past contributed in no small measure to the handicaps for diseminating necessary details on the discipline. One international scholar, (Albert, 2001:ix) has this to say: "A forceable problem for running these new programmes is a dearth of books. There are a plethora of books, journals and occational publications that could be used for teaching the programmes; but most of them were produced in America and Europe and therefore, are expensive for Nigerians to afford. In addition, the prescriptions of some of these publications do not address the reality of local African problems. This calls for more locally written books on African conflict situations. Another problem that has been identified is that most of the extant literature address war situations and therefore, have little or nothing to say about community conflicts” (Albert, 2001:ix).

Most of the books either authored or edited by Isaac Olawale Albert, an international acclaimed scholar of peace and conflict studies, are being used in many tertiary, Secondary and other Institutions in Nigeria particularly and globally as well. Some of those books that are of utmost relevance and stocked in various libraries include the followings: Community conflicts in Nigeria (1999), Building Peace, Advancing Democracy (2001), and Introduction to Third-Party Intervention in Community Conflicts (2001). Albert has also published several papers, both locally and internationally, on issues germane to peace and conflict. Equally of high relevance are literature books published by some Non-governmental organizations when it became obivous that inculcation of education for peace and justice is non-negotiable in many developing countries, especially, Nigeria. An NGO, which goes by the name - Conflict Resolution Stakeholders Network (CRESNET), has been involved in organizing Seminars in all the nooks and crannies of the geo-political zones of Nigeria, preaching peace and sermonizing on violence-free co-habitation. 
There are other programmes related to education for peace and justice which tend to be more focused on a specific dimension of peace. For example, education for human rights or justice or education for democracy-are often carried out with specific groups, such as state actors, soldiers, police, prison officials, non-state actors, and are usually linked to specific events. One example again is sermonizing when electoral processes are ongoing but as soon as they over, anything have to do with peaceful discussions are equally over. That is a problem in Nigeria.

At times, people are being organized and educated about their democratic rights, responsibilities and issues germane to violence-free activities for the good of their community.

It is important to state that in Nigeria, many Universities have established Institutes and Full fledged Departments, specifically for Peace and Conflict Studies, for the purpose of not only analysing the common features of conflict at various levels, from the personal to international, but also where modes of intervention are equally studied. Graduates from these Departments, collaborate with Peace and Conflict practitioners with a view to imparting knowledge gained into many peace volunteers, by way of teaching and practice, thereby contributing to global peace.

The essence of education for peace is to bring about positive change of attitudes and behavior, through which greater co-operation and mutual problem-solving propensities could be realized. This paper admits that peace education, in the formal sector, exists globally but subscribes to the belief that it is most successful when content and methods are developed locally, particularly, in response to communal, identified problems. These few remarks point to the relevance of literature as a core avenue for imparting education for peace and justice.

\subsection{Using Informal Channels for Education for Peace}

Conceptually, if formal education is about institutionally programmed activities, documented along specific lines, informal education is also a programmed set of activities pursued in accordance with the evolution of events as they arise. Whereas formal education has specific forums where people gather to receive lectures, informal education takes place in every space considered conducive, like market place, in remote areas of a community, in compounds, fields or any important venues, as long as the societal peace is not disturbed.

The idea of complementing formal peace education with informal type is because of a disadvantage in limiting peace education to schools and colleges where people often emphasize acquiring knowledge in order to earn success in examinations, rather than for practical purpose.

Empirical knowledge reveals that much peace education takes place in informal settings where people gather, either for lecture or other social activities. Similar to institutional experience, informal peace education addresses primarily attitudes and aims to have a direct impact on personal behaviour. This paper submits that in order to reap the positive reward of impacting peace education at either formal or informal settings, a relaxed atmosphere must be created, beyond "Lecturer/Pupil or Master Teacher/Must-listen -audience.” It must be synonymous with an unrestricted and an inviting forum, for people to feel encouraged to undertake the task of confronting issues in a win-win scenario. This can be done when they reflect on their own behavior and attitudes and start generating alternatives for the future. Through open-mindedness, people will become aware of their biases as well as prejudices inherent in their society.

Many scholars are brainstorming on the desirability of complementing education for peace and justice through "social studies" education. As social studies education deals with human beings in every ramification, one of its objectives, Adaralegbe (1980) posits, includes the development of sympathetic appreciation of the diversity and interdependence of all the members of a local community, as well as the national and international communities. Re-emphasizing this assertion, the scholar takes a cursory look at all the articles of the Universal Declaration of Human Rights, which elucidate the significance of social education as capable of inculcating in the citizenry the basic political socialization, from where they are taught their rights and duties as citizens. The irony of illiteracy is that it blindfolds people from any commitment of theirs to the state or society but promotes peoples agitation for their rights only. Such a situation encourages parochialism, at the expense of open-mindedness.

Where people clamour for their rights without thinking of a corresponding responsibility to the state, conflict will continue to be the order of the day. Social studies education, as a complement of education for peace and justice, teaches rules of etiquette such as equity, fairness, equality, patriotism, tolerance, co-operation, respect and the dignity of man. Lending his voice to this assertion is Jacob (1982) who asserts that through social studies education, various techniques, strategies and methodologies are learnt, which in turn could lead to the metamorphosis of those abstract issues into positive realities. Aina (1982) speaks-elaborately on social studies education which he says could be a socializing agent. Aina (1982) further submits that social studies education enables younger people to acquire the required knowledge and skills that could enable them live as functional, active and positive contributory members of the society. Contributing to the discussion about the positive contribution of social studies education, in terms of 
values, Aina et al (1982) further argue that the great emphasis the concept places on values contributes to a positive personality development, improvement of self-concept, increased acceptance of minority groups, and increased tolerance and accommodation of alien cultures. Unarguably, these qualities which are in consonance with the ideals of human rights, if pertinently inculcated, will go a long way in complementing education for peace and justice. Aina (Ibid) equally admonishes that social studies education will dowse tension, promote sense of individual rights as well as individual's responsibilities, and the society will experience greater harmony and progress. Individuals will appreciate the tenets of individualization which social work practice sees as the ability to differentiate a person from another fellow. Individuals can never be the same in both inherited and acquired personality traits, and that those traits must not be allowed to constitute the basis for prejudices, bias or exploitation, for this leads to man's inhumanity to man.

\section{Conclusion}

Education for peace and justice, if pertinently inculcated, will promote tolerance, guarantees unity and eliminate adversarial conflict. Most of the past conflicts in Nigeria and particularly the raging ones are due to issues, such as lack of understanding, misconceptions of felt-needs, besides the prevalence of greed and grievances, which combined to compound the much needed spirit of homogeneity for progress. Without any doubt, inculcating education for peace and justice, through both formal and informal channels, will go a long way in meeting the wide gaps of the felt-needs of the entire citizenry in the country.

One of the reasons why peace education succeeds is that the individuals feel themselves as being part and parcel of a whole system. The sense of belonging is there and there is recognition for the authority of the land. Such people feel a shared responsibility for their colleagues and equally believe that they all have a shared future which they must collectively programme for its future betterment.

It is a society where positive peace prevails that could be likened to one where its government empowers the governed to take an active part in decision making. Conversely, negative peace prevails where oppression and force are unleashed on the people, and have become the order of the day. People will tend to be passive, showing disinterest in fulfilling their social or political roles, because the government has not shown any willingness to either perform its statutory duties of care for whatever reason, and has not made any attempt or a worthwhile attempt to explain why it is handicapped. This is where the definition of negative peace offered by Galtung 2000:64; becomes instructive, thus:"the absence of war, organized military hostilities, or direct inter-personal or intergroup violence while the causes of the conflict remain ignored. Some peace researchers, such as J. Galtung, call this a "negative peace" because injustice and "structural violence" are allowed to continue (Galtung 2000:64) cited in A. P. Schimid, 2000:64, London. Any society where mutual understanding prevails between the governed and government, conflict will be handled creatively with a constructive result in such atmosphere, levels of participation will be high because there are channels for the expression of disagreement and corresponding mechanisms for handling disagreement and reaching consensus. As long as all the sections of the community have a voice, embracing all men and women, young and old, disabled and able-bodied, employed and unemployed, rich and poor, there will be a progressive and peaceful society. In conclusion, while conflict is inevitable in any society and its outcome rests on how it is handled, education for peace and justice aims at having a society where there is positive peace, predicated on the definition of Galtung (2000;64) thus:-“the absence of war and direct violence, plus the presence of social justice. It is a concept found in the works of Martin Luther King and John Galtung, indicating the absence of what Galtung calls "structural violence” which contributes to reducing the potential life span of human beings below what it might otherwise be. Under positive peace, there is an active presence of conflict management institutions that deal with social conflicts in fair and non-descriptive ways: (Galtung 2000:64, cited in A. P. Schmid 2000:64, London).

\section{Recommendations}

1. Education for peace and justice should be designed in a number of ways such as workshops, and awareness campaigns.

2. The formal channels, that is, through institutional settings, must be well staffed with personnel that are well grounded in peace and conflict studies. This should be complemented with "train the trainers" approach in order to ensure the adequacy of suitable knowledge transfer.

3. There must be in place good governance. Bullying on people or autocracy, where democracy is being practiced, is an invitation to anarchy. It is the combination of institutions, laws, and norms that give room to 
people for expressing their concerns and fight for their interests within a predictable and relatively equitable context. This is the basis of good governance.

4. Misuse of power by the government must be avoided. The government must take cognizance of the fact that public authority must be sanctioned by the consent of the governed.

5. Due to the level of literacy in the developing countries, where the level of illiteracy outstrips that of the literacy, informal education for peace must be given greater emphasis as the majority of people in that category can jeopardize the far-reaching efforts of the minority who are better informed.

6. The use of internet and other means of information technology will enhance the dissemination of education for peace and justice in Nigeria.

\section{References}

Ajayi, J. F. A., \& Smith, R. (1964). Yoruba Warfare in the Nineteenth Century. Gambridge: Gambridge University Press.

Akinjogbin, I. A. (1965). Prelude to the Yoruba Civil Wars of the $19^{\text {th }}$ Century. Odu, University of Ife Journal of African Studies, 2.

Akinjogbin, I. A. (1966). The Oyo Empire in the $19^{\text {th }}$ Century: A Reassessent. Journal of Hisotrical Society of Nigeria, III, 3.

Akinjogbin, I. A. (1992). Ife: The years of Travail, 1793 - 1893. In I. A. Akinjogbin (ed.), The Cradle of Race: Ife from the beginning to 1980, Port-Harcourt: Sunray Publications.

Akintoye, S. A. (1971). Revolution and Power Politics in Yorubaland, 1840 - 1843. Ibadan: Longman.

Albert, I. O. (1999). "Ife-Modakeke Crisis" in Onigu Otite and Isaac Olawale Albert, Community Conflicts in Nigeria (1999, 142-183), Ibadan, Spectrum Books Ltd.

Albert, I. O. (2001). Introduction to Third Party Intervention in Community Conflicts. Ibadan: John Arechers.

Anderson, J. (2000). Religion and International Relations. In Trevor C. Salmin and Mark F. Imber (2000:213), London: Raurledge.

Appadoria, A. (1974). The substance of Politics. New Delhi: Oxford University Press.

BBC. British Broadcasting Corporation (2014). Ethics-War: Pacifism. Retrieved 29/10/2016 from http:www.iepoutm.edu/pacifism

Brock, A., \& Socknat, E. (1999). Challenge to Mrs: Essys on Pacifism from 1918 - 1945. Toronto: University of Toronto Press. https://doi.org/10.3138/9781442672796

Dahl, R. A. (2003). Modern Political Analysis. London: Prentice Hall.

For Aina, S. A., \& Jacob, A. (1982). Human Rights Today. Amnesty International, 4(1), 1-15.

Galtung, J. (2000). Peace by Peaceful Means. In A. P. Schmid (2000), Thesaurus and Glossary of Early Warning and Conflict Prevention terms. London: Forum on Early Warning and Early Response.

Ikime, O. (1984). Ground work of Nigerian History. Ibadan: Heinemann Educational Books (Nigeria) Ltd.

Johnson, S. (1973). The History of the Yorubas. Lagos: CMS.

Law, R. C. C. (1970). Chronology of the Yoruba Wars of the Early Nineteenth Century. Journal of the Historical Society of Nigeria, Nigerian Tribune, April 7, 16, 17, 18, 21, 1981, May 26, 1981.

Nye, J. S., Jnr. (2007). Understanding International Conflict: An Introduction to Theory and History. New York: Longman.

Orend, B. (2000). War and International Justice: A Kantian Perspective. Wifrid: Laurier University Press.

Otite, O. (1999). On Conflicts, Their Resolution, Transformation, and Managing. In Onigu Otite and Isaac Olawale Alber (Eds.), Community Conflicts in Nigeria (1999:1) Ibadan Spectrum Book Ltd.

Robins, K. (1976). The Abolition of War: the peace Movement in Briterin, 1914 - 1919. Wales: University of Wales Press.

Sabine, G.H., \& Thorson, T.L. (1973). A History of Political Theory $\left(4^{\text {th }}\right.$ Ed.). New Delhi: Oxford \& IBH Publishing 
Co. PVT. Ltd.

Salmon, T. C., \& Imber, M. F. (2000). Issues in International Relations. London: Routledge.

Schmid, A. P. (2000). Thesaurus and Glossary of Early Warning and Conflict Prevention terms. London: Forum on Early Warning and Early Response.

Teichaman, J. (1986). Pacifism and the Just War: A study in Applied Philosophy. Landen: Basil Blockwell.

Teti, A. (2008). Political Islam. In Trevor C. Salmon and Mark F. Imber, (2008: 218-234), International Relations. London: Routledge.

Whittaker, D. T. (1999). Conflict and Reconciliation in the Contemporary world. London and New York: Routledge. https://doi.org/10.4324/9780203264577 